\title{
ANALISA APLIKASI PENGGAJIAN PADA SPBU MURI TEGAL MENGGUNAKAN VISUAL BASIC 6.0
}

\author{
Arif Rakhman ${ }^{1}$, Dita MelaAnggraeni ${ }^{2}$ \\ E-mail:Cakrakirana7@gmail.com,ditamela95@gmail.com, \\ DIII Teknik Komputer Politeknik Harapan Bersama \\ Jln. Mataram No. 09 Tegal Telp/Fax (0283) 352000
}

\begin{abstract}
Abstrak
Sebagai salah satu penerimaan yang sah akibat hubungan kerja, gaji adalah salah satunya, dimana setiap karyawan yang berkerja pada suatu instansi berhak untuk mendapatkan gaji berdasarkan peraturan atau ketentuan pengajian yang berlaku disebuah instansi.Masalah yang timbul dalam penggajian karena belum adanya bentuk laporan gaji dan masih menggunakan sistem manual (Microsoft exel) sehingga banyak waktu yang terbuang. Aplikasi Penggajian dapat membantu agar waktu tidak terbuang dengan percuma sehingga lebih efektif dan efisien. karena itu perlu adanya suatu pengintegrasian yang khusus dalam wujud pemograman aplikasi dengan menggunakan Microsoft Visual Basic 6.0. maka dari itu melalui Tugas Akhir (TA) ini diambil sebuah judul "aplikasi penggajian karyawan pada SPBU muri tegal menggunakan visual basic 0.6" dengan menggunakan microsoft visual basic 6.0".Aplikasi Penggajian ini dapat mempercepat proses pemberian gaji kepada para karyawan SPBU Muri Tegal dan disesuaikan dengan jabatan yang dimiliki karyawan.
\end{abstract}

Kata kunci: aplikasi, penggajian, visual basic 6.0.

\section{Pendahuluan}

Sebagai salah satu penerimaan yang sah akibat hubungan kerja, gaji adalah salah satunya, dimana setiap karyawan yang bekerja pada suatu instansi berhak untuk mendapatkan gaji berdasarkan peraturan atau ketentuan penggajian yang berlaku di sebuah instansi. Mengingat setiap pekerja dalam organisasi mempunyai pengharapan atas sesuatu dari organisasi, sebagai penghargaan atas jerih payah pekerja selama bekerja.

Masalah pemberian gaji bukan hanya penting Karena merupakan dorongan utama seseorang untuk menjadi karyawan, tetapi juga karena gaji yang diberikan ini mempunyai pengaruh yang sangat besar terhadap semangat dan kegairahan kerja parakaryawan organisasi. Gaji merupakan sesuatu yang sangat penting sebagai pendapatan bagi parakaryawan sehingga diperlukan suatu system pengolahan data penggajian yang tepat.

Begitu juga di SPBU Muri Tegal ini yang berada di Jl. Dampyak Km 43 Tegal yang memberikan pelayanan pengisian BBM mempunyai lebih dari 30 karyawan.

Sistem aplikasi penggajian merupakan salah satu bentuk perangkat lunak yang dapat menghitung gaji yang akan diterima setiap karyawan. Saat ini system penggajian yang diterapkan di SPBU Muri Tegal masih menggunakan sistem manual yang masih memungkinkan terjadinya kesalahan pemasukan data sehingga sering terjadi keterlambatan dalam penerimaan data yang berhubungan dengan data - dat gaji dan mengakibatkan kinerja yang ada menjadi tidak efektif. Berdasarkan permasalahan tersebut maka dibuatlah Judul Penelitian ini adalah "Aplikasi Penggajian Pada SPBU Muri Tegal Menggunakan Visual Basic 6.0

\section{Metode Penelitian}

Berdasarkan uraian latar belakang diatas, maka rumusan masalah dalam penelitian ini adalah, bagaimana membuat aplikasi penggajian karyawan SPBU Muri Tegal menggunakan Visual Basic 6.0, untuk mengurangi kesalahan dan mempercepat proses pemberian gaji.

Dalam hal ini pembahasan masalah hanya dibatasi pada hal - hal yang berhubungan dengan pembuatan program untuk aplikasi gaji karyawan SPBU Muri Tegal menggunakan Tools yang digunakan Microsoft Visual Basic 6.0danMYSQL. 
Tujuan dibuatnya aplikasi penggajian karyawan SPBU Muri Tegal menggunakan Microsoft Visual Basic 6.0 adalah untuk mengatasi kendala supaya lebih efektif dan efesien dalam memberikan gaji untuk karyawan SPBU Muri Tegal.

Dengan adanya aplikasi penggajian diharapkan dapat meminimalkan kesalahan dalam penggajian, dan diharapkan juga dapat mempermudah dan mempercepat prosses penggajian karyawan pada SPBU Muri Tegal.

\section{Metode Penelitian}

a. Rencana / Planing

Metode dalam perencanaan suatu penelitian yaitu pengumpulan data dengan melakukan pengamatan atau dating langsung kelokasi untuk mendapatkan data yang akurat. Data - data yang dicari dan dibutuhkan dalam pembuatan laporan ini adalah sebagai berikut:

1) Sekilas tentang SPBU Muri Tegal

2) Struktur Organisasi

3) Data karyawan

4) Lampiran-lampiran

5) Analisis

b. Jenis Metode

Jenis pengumpulan data yang digunakan dalam pembuatan laporan ini adalah metode Deskriptif, yaitu metode pembahasan masalah yang digunakan untuk menggambarkan objek yang diteliti dengan cara mengumpulkan data dan menganalisa data yang diperoleh.

\section{c. Implementasi}

Hasil dari penelitian akan diuji cobakan dan diterapkan dahulu untuk menilai seberapa baik aplikasi yang telah dibuat serta memperbaiki bila adakesalahan - keesalahan yang terjadi. Dan hasil dari ujicoba aplikasi, kemudian akan di implementasikan di SPBU Muri Tegal.

\section{d. Metode Pengumpulan Data}

Metode dalam perencanaan suatu penelitian yaitu pengumpulan data dengan melakukan pengamatan atau dating langsung kelokasi untuk mendapatkan data yang akurat. Data - data yang dicari dan dibutuhkan dalam pembuatan laporan ini adalah sebagai berikut:

1. SekilastentangSPBUMuriTegal

2. StrukturOrganisasi.

3. Data karyawan.

4. Lampiran-lampiran.

5. Analisis

\section{Hasil dan Pembahasan}

Sistem pengolah penggajian karyawan yang ada di SPBU Muri saat ini memang sudah terkomputerisasi, namun sebagian masih dikerjakan dengan menggunakan Microsoft Office Excel 2007 yang masih memunginkan terjadinya kesalahan pemasukan data sehingga sering terjadi keterlambatan dalam penerimaan data yang berhubungan dengan data - data gaji dan mengakibatkan kinerja yang ada menjadi tidakefektif.

a. Dari permasalahan diatas perlu adanya sebuah penelitian yang sekarang ada menjadi sistem yang lebih baik dengan system terintegrasi. Dengan system informasi teknologi tersebut, maka dibutuhkan perancangan system untuk mengolah data karyawan, sehingga menjadi suatu informasi yang lengkap dan terperinci. Dengan dukungan system informasi terintegrasi cara kerja lebih efisien.

b. Analisa permasalahan merupakan penguraian dari suatu system informasi yang lengkap dan terperinci. Dengan dukungan system informasi yang utuh kedalam bagian komponenkomponennya dengan maksud untuk mengidentifikasi dan mengevaluasi permasalahan-permasalahan atau hambatan-hambatan yang terjadi menyesuaikan kebutuhan yang diharapkan sehingga dapat diadakan perbaikan. Analisa dapat dilakukan untuk mengetahui masalah apa yang sedang dihadapi oleh sebuah instansi atau lembaga yang berguna untuk membandingkan dan membuat pilihanpilihan yang diberikan pada system baru. 


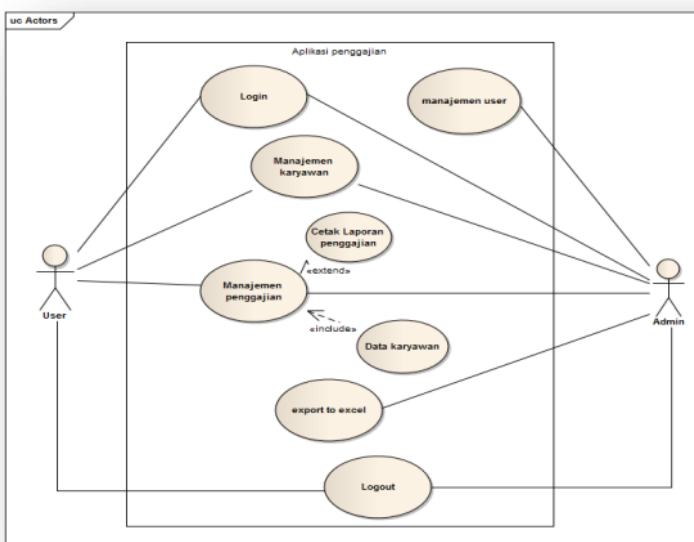

Gambar 1.Use Case AplikasiPenggajian.

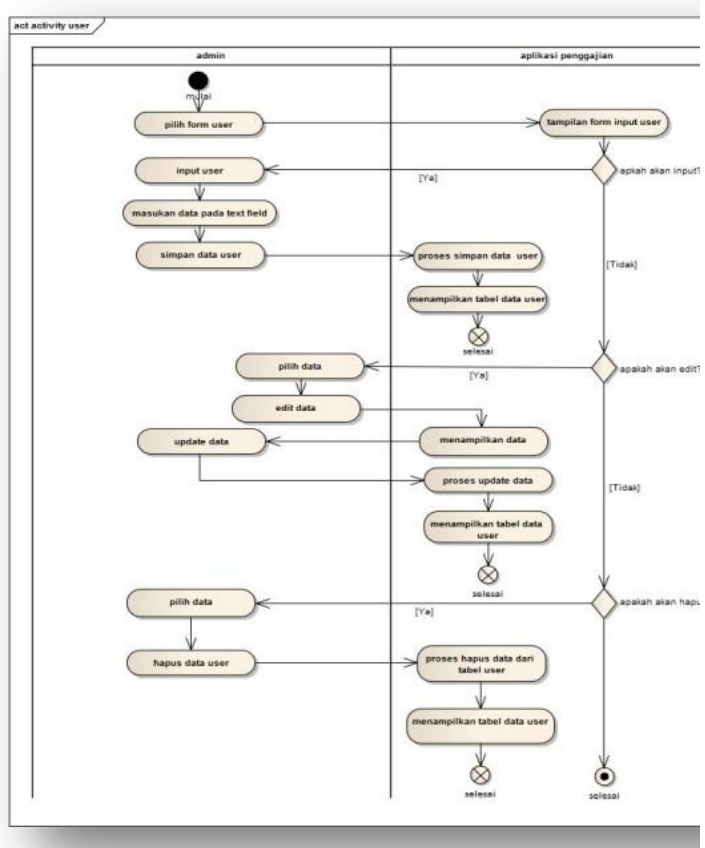

Gambar 2. Activity Diagram Input user

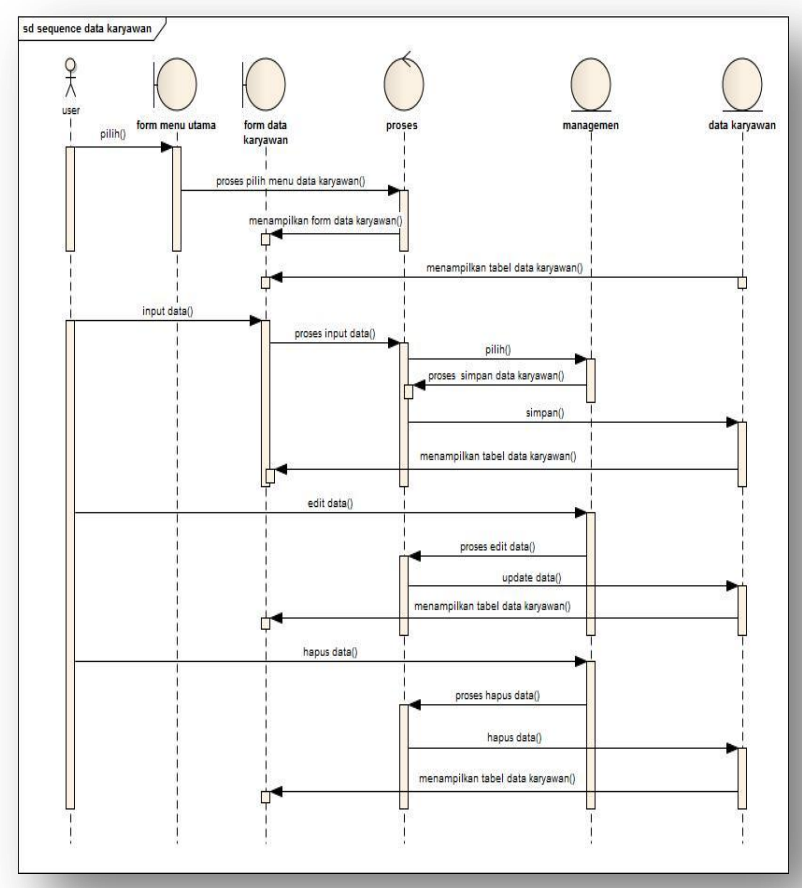

Gambar 3. Sequence Diagram Data Karyawan

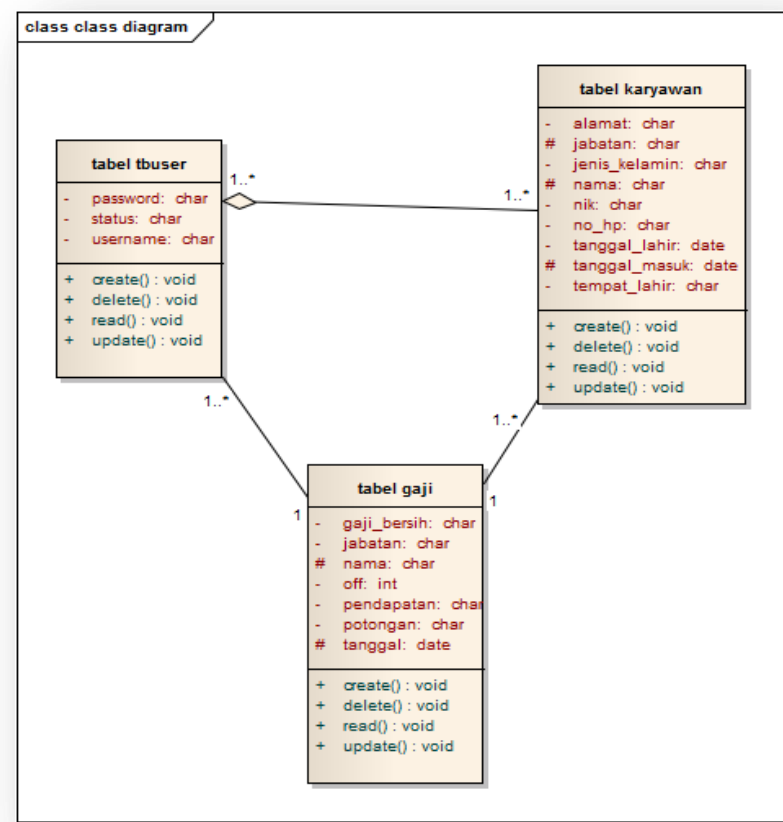

Gambar 4.Class Diagram. 


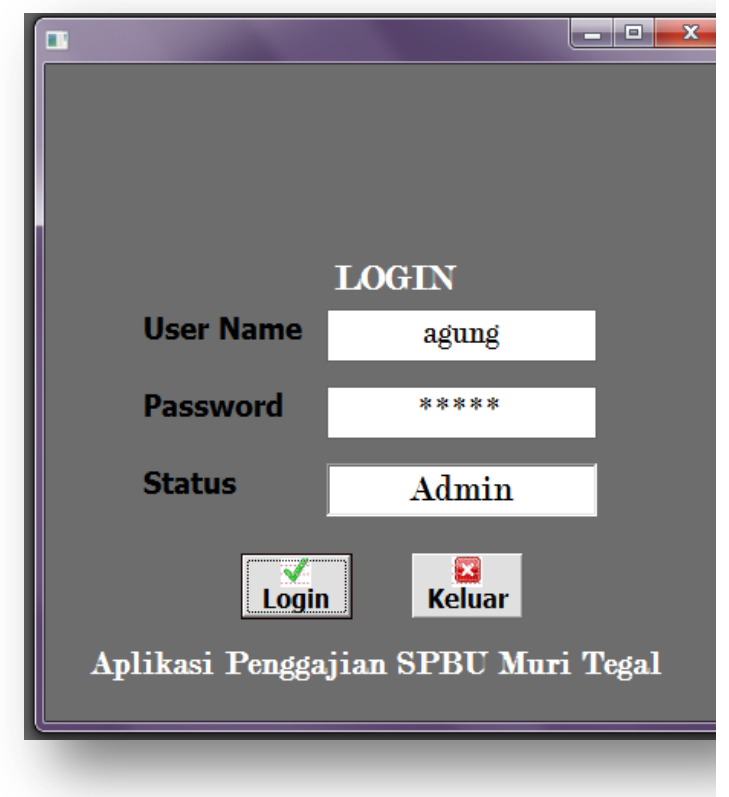

Gambar 5.Tampilan Form Login

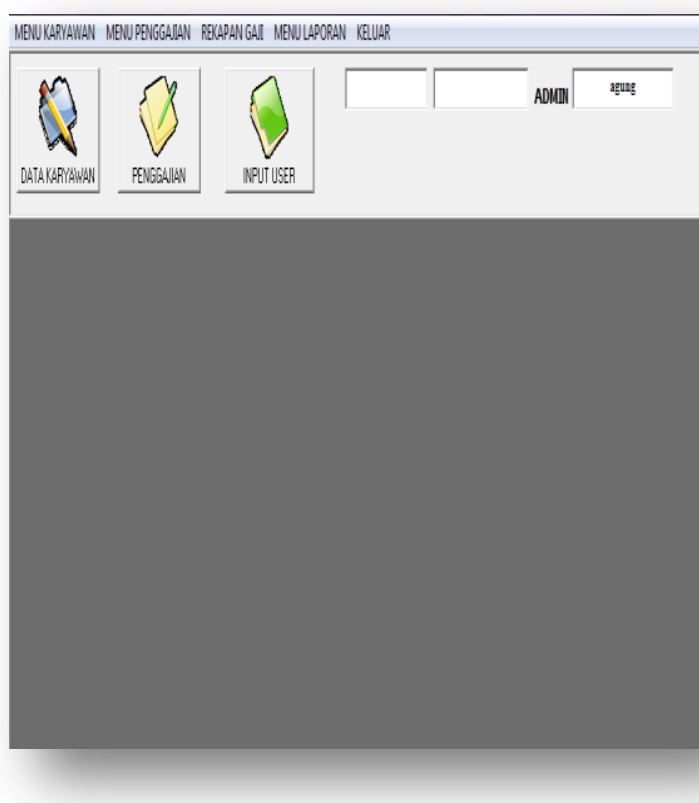

Gambar 6. Tampilan Form Menu Utama.

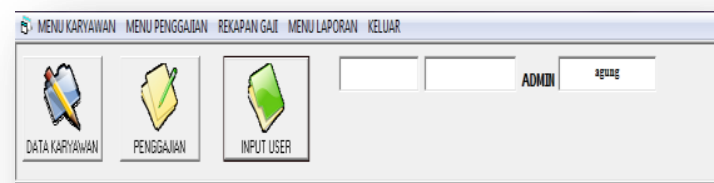

FORMIDATA LSER

SPBU MIRI TEGAL
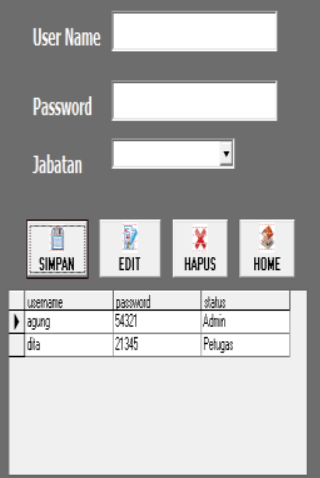

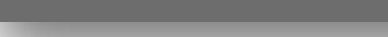

Gambar 7.TampilanForm User

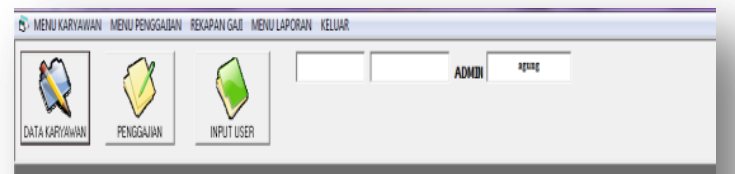

DATA KARVITIAN SPBU NITRI TEGAL

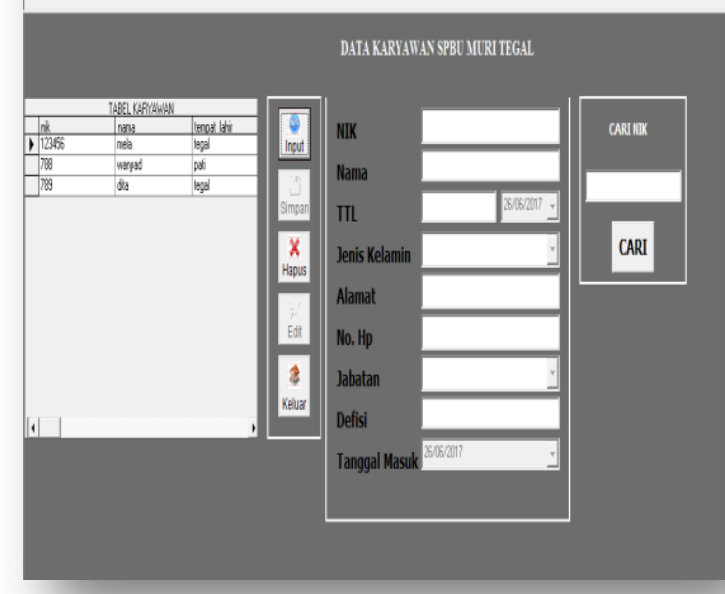

Gambar 8.TampilanForm Data Karyawan. 


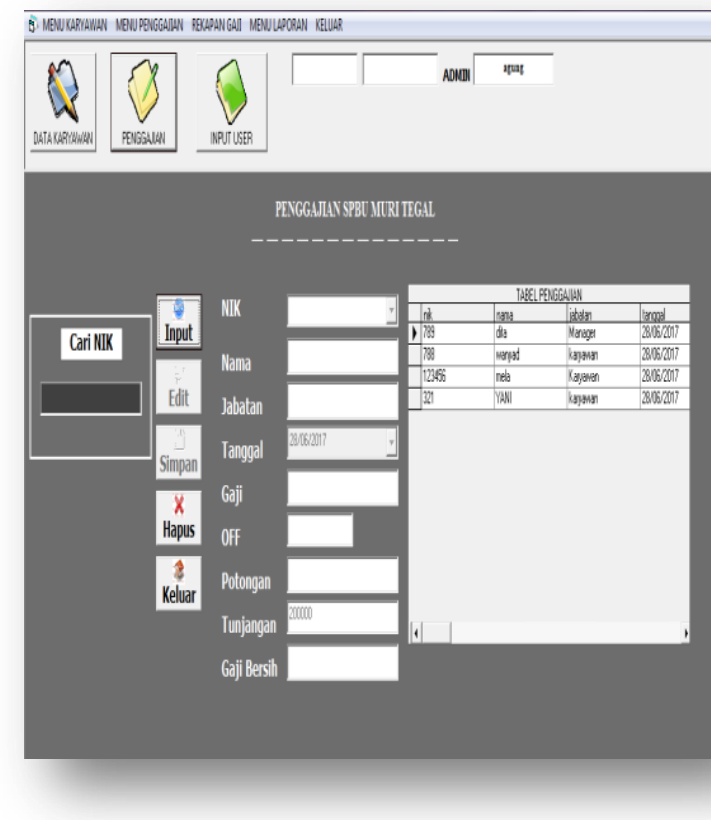

Gambar 9.TampilanForm Penggajian

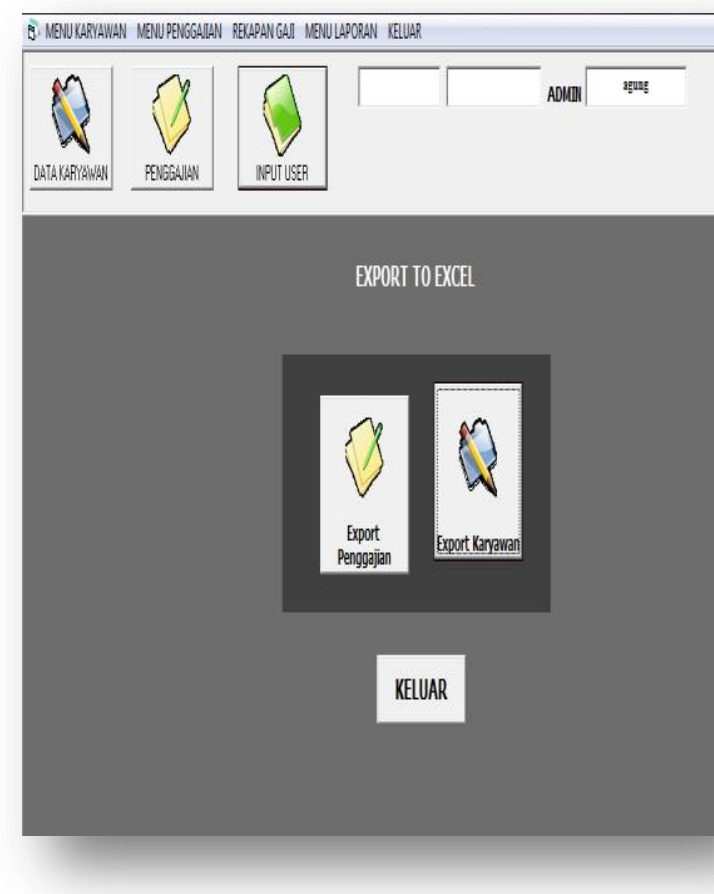

Gambar 10. Tampilan Form Export To Excel

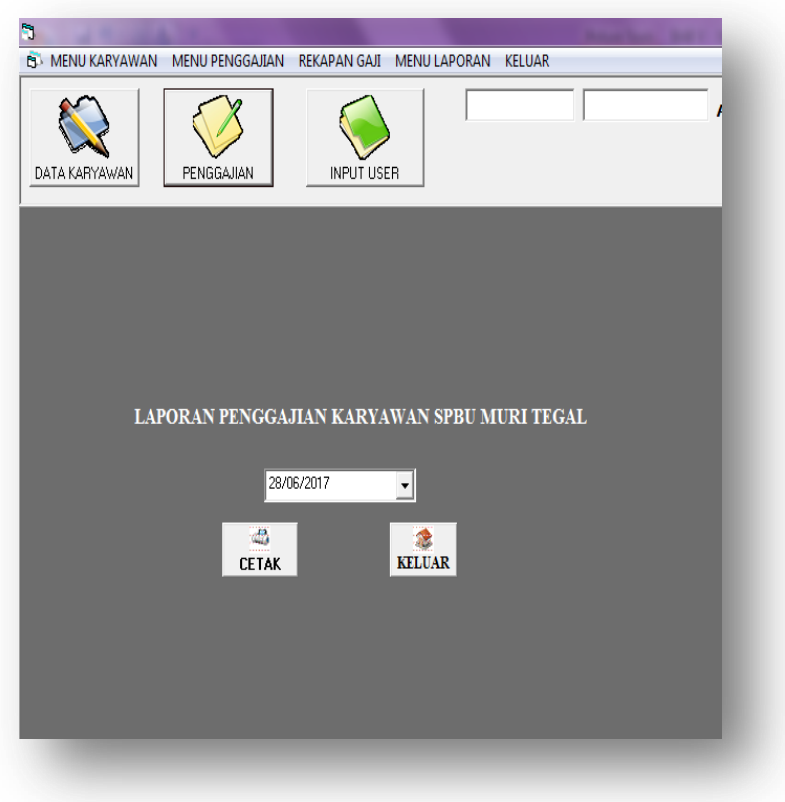

Gambar 11.TampilanFormLaporan Gaji

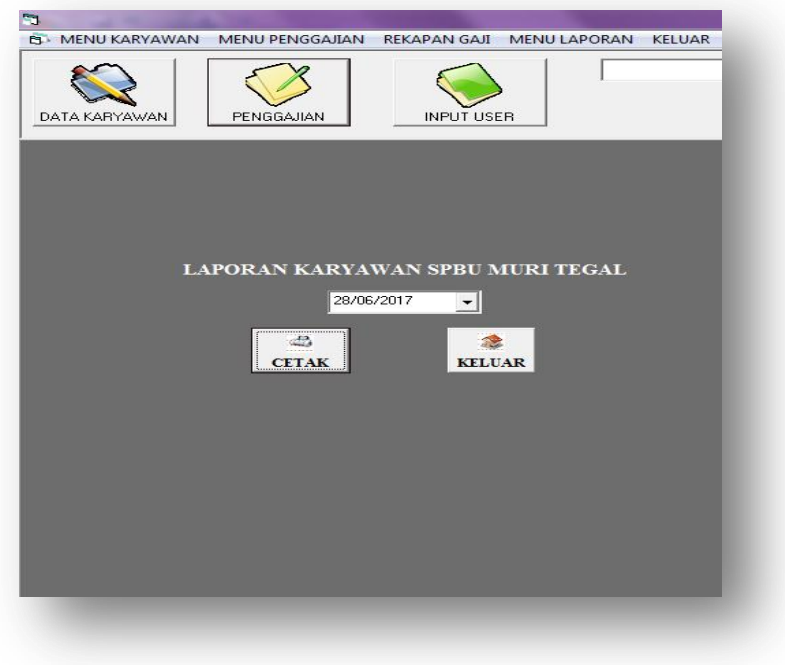

Gambar 12.TampilanFormLaporankaryawan

\section{Kesimpulan}

Dengan menggunakan bahasa pemograman Microsoft Visual Basic 6.0, database MySQL dan model perancangan menggunakan Unified Modelling Language (UML) serta laporan menggunakan Crystal Reports, Sistem Penggajian yang dibuat dapat mempermudah pihak yang berkepentingan untuk mendapatkan informasi secara cepat dan akurat serta mengurangikesalahan proses penggajian di SPBU Muri. Aplikasi Penggajian ini dapat mempercepat proses pemberian gaji kepada para karyawan SPBU Muri dan disesuaikan 
dengan jabatan yang dimiliki karyawan. Proses perhitungan gaji tersebut menghasilkan laporan data gaji dan daftar karyawan yang akan dilaporkan kepada Manager SPBU Muri serta slip gaji yang berisi rincian gaji karyawan yang kemudian akan diserahkan kepada masing-masing karyawan sebagai bukti pembayaran gaji.

\section{Daftar Pustaka}

[1.] Andi, Seri Panduan Pemograman Database Visual Basic 6.0 dengan Crystal Report, MADCOMS, Yogyakarta 2010

[2.] Davis, G.B, Sistem Informasi Manajemen Penggajian, PT. Pustaka Binaman Presindo, 1993

[3.] Fadheli, Chairul. 2012. Pengertian Mysql. Tersedia :www.maniacms.web.id/pengertianmysql.html.

[4.] Kok, Yung. 2002. Membangun Database dengan Visual Basic 6.0 dan Perintah SQL. Jakarta : PT Elex Media Komputindo.

[5.] Octhovhiana, K.D 2003. Cepat Mahir Visual Basic 6.0. Jakarta :Ilmu Komputer.Com

[6.] Prabowo P. W. 2011.Unified Modelling Language : Belajar UML. Jakarta : Andi Publisher

[7.] Prasetyo Eko. 2008. Pemograman Visual Basic 6.0 untuk Sistem Informasi Penggajian. Yogyakarta : Graha Ilmu.

[8.] Rucky S Achmad. 2006. Manajemen Penggajian dan pengupahan untuk karyawan perusahaan. Jakarta, 2000

[9.] Simon Bennett., et all, "Object Oriented Systems Analysis and Design Using UML", Computer Science Series, Mc Graw-Hill International Editions.

[10.]Handoko. 2002. Definisi Penggajian Menurut Para Ahli. [Online]. Tersedia:http://www.AhliPenggajian. Com/Definisi.Penggajian. 